\title{
The gastralial apparatus of Plateosaurus engelhardti: morphological description and soft-tissue reconstruction
}

\author{
Regina Fechner and Rainer Gößling
}

\begin{abstract}
The fragmentary nature of the fossil record of the gastralial apparatus of sauropodomorph dinosaurs has considerable impact on our understanding its functional morphology and evolution in this group. With the aim of increasing our knowledge on the functional morphology of the gastralial apparatus of sauropodomorph dinosaurs, remains of the gastralial apparatus of Plateosaurus engelhardti are described. Soft-tissues and their function are reconstructed applying the Extant Phylogenetic Bracket, in this instance comprising crocodiles and birds. The gastralial apparatus of Plateosaurus consists of at least 18 gastralial rows. With exception of the $1^{\text {st }}$ row, which has a chevron-shaped medial and two lateral gastralia, the gastralial rows consist of two medial and two lateral gastralia. The lateral gastralia are $2.2-2.8$ times longer than the associated medial gastralia. The proximal ends of the medial gastralia overlap in a latticelike arrangement, forming a mid-ventral imbricating articulation. Characteristic for Plateosaurus is the sigmoid form of the medial and lateral gastralia, the increasing angle of the gastralial rows from proximal to distal, as well as the increasing robustness of the gastralia rows from proximal to distal. According to the Extant Phylogenetic Bracket, the gastralial apparatus of Plateosaurus is embedded into M. rectus abdominis, which attaches to the caudal aspect of the sternum and indirectly to the distal end of the pubis. As in extant archosaurs, $m$. rectus abdominis is closely related to the other muscles of the hypaxial abdominal muscle group. The muscles of the hypaxial abdominal muscle group are active during ventilation and locomotion, which suggests that the functions of the gastralial apparatus of Plateosaurus may be more complex than previously suggested.
\end{abstract}

Regina Fechner. Biomechanics Research Group, Fakultät für Maschinenbau, Ruhr-Universität Bochum, Universitätsstraße 150, 44801 Bochum, Germany. fechner@Imk.rub.de

Rainer Gößling. Biomechanics Research Group, Fakultät für Maschinenbau, Ruhr-Universität Bochum, Universitätsstraße 150, 44801 Bochum, Germany. goessling@Imk.rub.de

Keywords: "belly ribs"; hypaxial abdominal muscles; Sauropodomorpha; trunk stabilization

Fechner, Regina and Gößling, Rainer. 2014. The gastralial apparatus of Plateosaurus engelhardti: morphological description and softtissue reconstruction. Palaeontologia Electronica Vol. 17, Issue 1;13A; 11p; palaeo-electronica.org/content/2014/696-gastralia-of-plateosaurus 


\section{INTRODUCTION}

Gastralia are dermal ossifications localized in the ventral or ventroposterior abdominal wall of several extinct tetrapodan groups (see Claessens, 2004), as well as some extant reptiles, such as Sphenodon punctatum (e.g., Daiber, 1920-21; Byerly, 1925) and crocodiles (e.g., Gadow, 1882; Maurer, 1896; Romer, 1956). In dinosaurs, remains of a gastralial apparatus are reported from numerous theropod dinosaurs and an increasing number of non-sauropodan sauropodomorph dinosaurs. The gastralial apparatus of theropod dinosaurs is known from many findings with more or less complete and articulated material (e.g., EudesDeslongchamps, 1838; Osborn, 1906; Lambe, 1917; Gilmore, 1920; Barsbold, 1983; Chure and Madson, 1996; Norell and Makovicky, 1997; Claessens, 2004; O'Connor, 2007). The theropodan gastralial apparatus consists of a variable number of metameric gastralial rows; each of these comprises four gastralia: two medial and two lateral gastralia. Exceptions are the fused and chevronshaped medial gastralium of the first and the last gastralial row reported from some theropod dinosaurs (Claessens, 2004). The gastralial apparatus of non-sauropodan sauropodomorph dinosaurs is mainly known from isolated and fragmentary material (e.g., Huene, 1907-08; Cooper, 1981; Knoll, 2010; Sertich and Loewen, 2010; Yates et al., 2010). However, an almost complete and articulated gastralial apparatus of Plateosaurus gracilis was described by Huene (1915), which received, unfortunately, little attention. The gastralial apparatus was lost on the lineage to sauropod dinosaurs (see Claessens, 2004), although remains of sauropodan gastralia have been repeatedly reported (Redman and Filla, 1994; He et al., 1998; Sereno et al., 1999). The most recent report on sauropodan gastralia was provided by Tschopp and Mateus (2013). When describing the remains of the chest region of Diplodocidae from the Late Jurassic Howe Quarry (Wyoming, USA), Tschopp and Mateus (2013) identified some of the material as gastralia. The assignment of this material to gastralia, however, is uncertain and solely based on a proposed articulation of the remains. Since these remains show morphological characters which clearly allow for an assignment to sauropodan sternalia (in the absence of morphological characters allowing for definitive assignment to gastralia) the remains are considered here as sauropodan sternalia. Findings on the gross anatomy and function of the sauropodomorph gastralial apparatus are mainly inferred from comparison with theropod dinosaurs (Claessens, 2004).

Assumptions on the functional morphology of the gastralial apparatus in saurischian dinosaurs as in other extinct and extant tetrapods are mainly based on its location on the ventral aspect of the trunk and on its association with $\mathrm{m}$. rectus abdominis and the activity of this muscle in extant tetrapods. Basically two different functions are discussed for the gastralial apparatus of saurischian dinosaurs: 1) protection and support of the viscera (Romer, 1956; Hildebrand, 1995; Holtz and Brett-Surman, 1997) and 2) respiration (e.g., Perry, 1983; Carrier and Famer, 2000; Claessens, 2004, 2009). In addition to the discussion on the function of the gastralial apparatus in saurischian dinosaurs, Robinson $(1975,1977)$ presented an interesting idea on the function of the gastralial apparatus in plesiosaurs. According to Robinson $(1975,1977)$, the ventral trunk of plesiosaurs including the gastralial apparatus and its associated soft-tissues were adapted to stresses that are exerted on the plesiosaurian trunk during aquatic locomotion. A fresh look at the activity pattern of the abdominal hypaxial muscles including $\mathrm{m}$. rectus abdominis in extant amphibians and reptiles has revealed that this muscle group is not only part of the respiratory system, but is also part of the locomotory system (e.g., Carrier, 1990; O'Reilly et al., 2000; Bennett et al., 2001).

Based on these new findings on the complex activity pattern of the abdominal hypaxial muscle group, a new hypothesis is introduced: the function for the gastralial apparatus comprises trunk stabilisation in Plateosaurus. In order to discuss this new hypothesis, we offer here: i) the description of the gastralial apparatus of Plateosaurus engelhardti and ii) the reconstruction of the soft-tissues that attach to the gastralial apparatus applying the Extant Phylogenetic Bracket (EPB) approach.

\section{MATERIAL AND METHODS}

The description of the gastralial apparatus of Plateosaurus engelhardti is based on three specimens, SMNS 12949 (Figure 1.1-2), SMNS 12950 (Figure 1.3), and SMNS 52968 (Figure 1.4-5). The remains of these specimens are articulated and almost complete (see below). In addition to providing new insights into the morphology of the gastralial apparatus of Plateosaurus engelhardti, these remains are associated with other postcranial material that allow for the assignment to the genus Plateosaurus (see Schoch, 2011). According to R. Schoch (pers. communication May 2013), the 

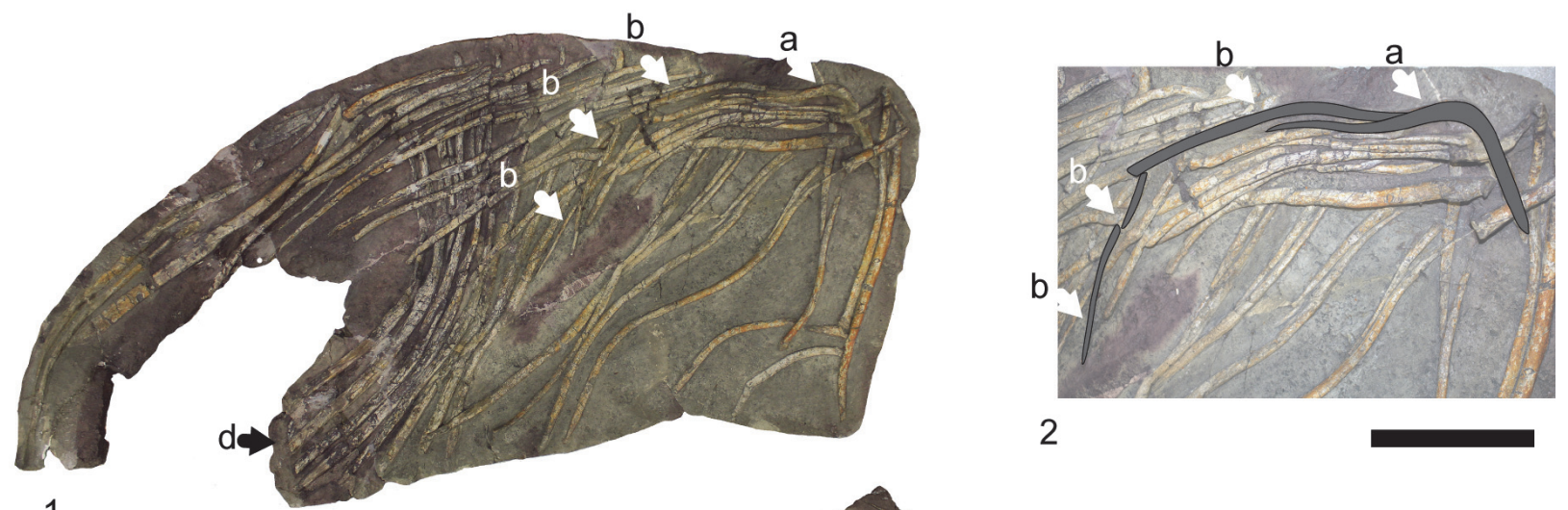

1
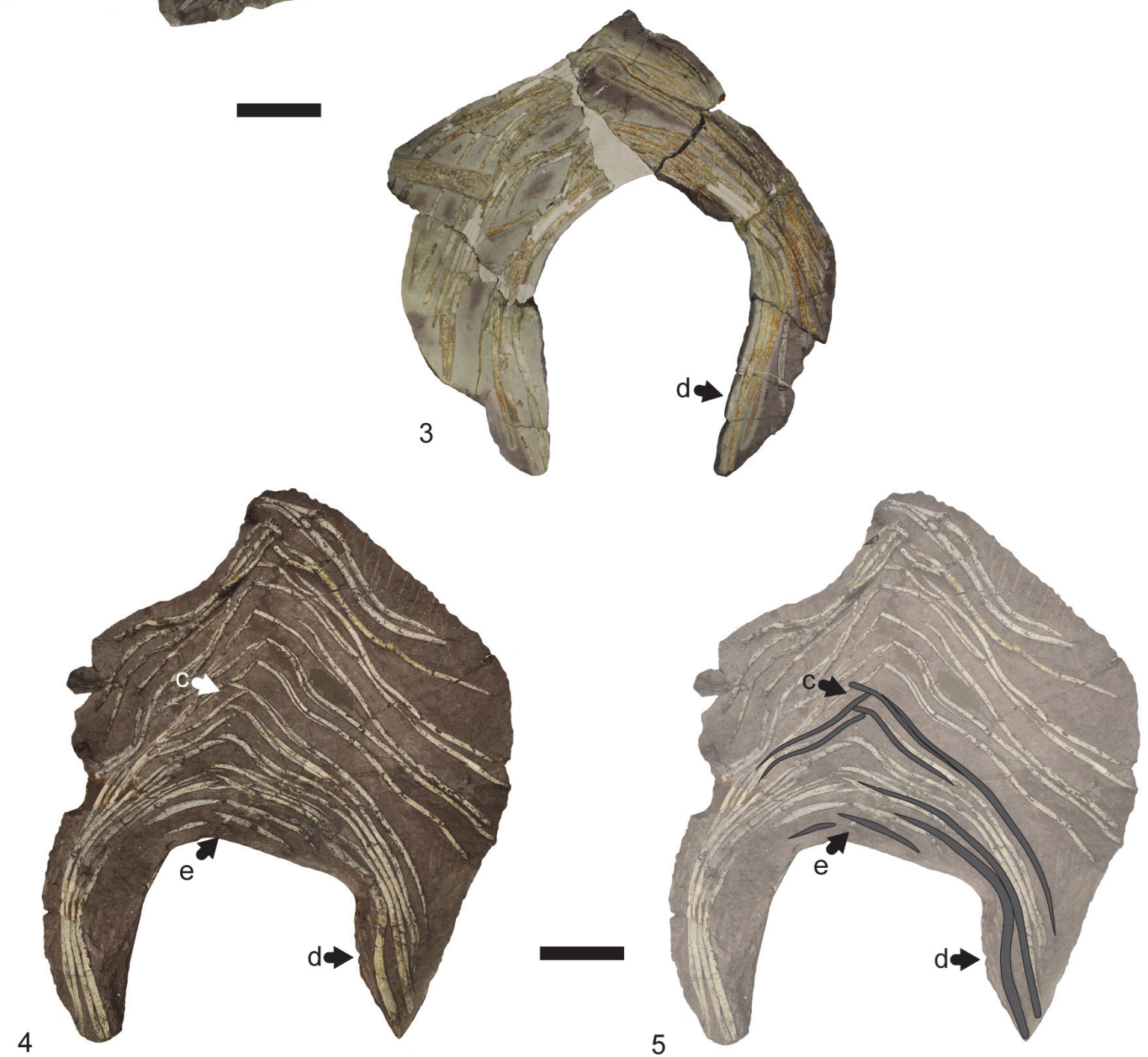

FIGURE 1. Gastralial apparatus of Plateosaurus engelhardti. 1, SMNS 12949; 2, interpretative drawing of the chevron-shaped medial gastralial of SMNS 12949; 3, SMNS 12950; 4, SMNS 52968; 5, interpretative drawing the midventral imbricating articulation, robust posterolateral gastralia and the last gastralial row of SMNS 52968. Arrows indicate $a$, chevron-shaped medial gastralium and b, lateral gastralium associated to the chevron-shaped medial gastralium; c, mid-ventral imbricating articulation; d, robust posterolateral gastralia, last gastralial row. Scale bar equals 10 $\mathrm{cm}$. 
Trossingen Plateosaurus material represents only a single species, Plateosaurus engelhardti. Although the material is exceptionally well preserved, the entire range of intraspecific morphological variation will not be detected within the gastralial apparatus of Plateosaurus engelhardti due to the limited number of specimens currently available for study.

SMNS 12949. An almost complete gastralial apparatus including the first gastralial row but lacking the caudalmost gastralial rows. Left and right pairs of the gastralial rows are displaced relative to each other. The articulation of medial and lateral gastralia of a gastralial row is preserved in situ. Sixteen rows are preserved.

SMNS 12950. An almost complete and articulated gastralial apparatus. SMNS 12950 lacks the cranialmost and caudalmost gastralial rows. The gastralial apparatus is preserved in situ without displacement. Unfortunately, the medial articulation of the gastralial rows is not preserved. Twelve rows are preserved.

SMNS 52968. An almost complete and articulated gastralial apparatus. Cranialmost rows are lacking, but SMNS 52968 includes the caudalmost row of the gastralial apparatus. The articulation of left and right pair of a set are slightly displaced relative to each other in the cranial part of the preserved gastralial apparatus. The articulation of a medial and lateral gastralial set is preserved in situ. Fifteen gastralial rows are preserved. The ventral aspect of the gastralial apparatus is exposed.

The anatomical description of the gastralial apparatus of Plateosaurus presented here is based on all three specimens. Specimen SMNS 12949 was used to reconstruct the cranialmost aspect of the gastralial apparatus of Plateosaurus, and specimen SMNS 52968 was used to reconstruct the caudalmost aspect of the gastralial apparatus. Measurements on length of medial and lateral gastralia, angle of paired sets of gastralia were mainly taken from SMNS 52968. The specimens were documented with drawings and photographs. Measurements were taken with a measuring tape.

For reconstructing the soft-tissue arrangement of the ventrolateral abdominal wall of Plateosaurus, the EPB approach was applied (sensu Witmer, 1995). Extant crocodiles (Caiman crocodylus, Crocodylus niloticus) and birds (Rhea americana, Gallus gallus) were dissected with special emphasis on the soft-tissues of the ventrolateral abdominal wall (origin and insertion of muscles, bone-muscle interaction, presence of cartilage). Additional information on the ventrolateral abdomi- nal wall of extant archosaurs was taken from the literature. For crocodiles, Gadow (1882), Maurer (1896), Romer (1923), Cong et al. (1998), Farmer and Carrier (2000) and Fechner and SchwarzWings (2013) were consulted. Fedde (1987), Baumel et al. (1990), Vanden Berge and Zweers (1993) and Vollmerhaus (2004) were chosen for gaining more insights into the myology of the ventrolateral abdominal wall of birds. Information on the function of muscles of the ventrolateral abdominal wall was taken from Gans and Clark (1976) and Farmer and Carrier (2000) for crocodiles and Fedde (1987), Baumel et al. (1990), and Vollmerhaus (2004) for birds.

\section{Institutional Abbreviations}

GPIT, Geologisch-Paläontologisches Institut Tübingen (GPIT), Germany; SMNS, Staatliches Museum für Naturkunde Stuttgart (SMNS), Germany.

\section{RESULTS}

\section{Morphology of the Gastralial Apparatus of Plateosaurus engelhardti}

The gastralial apparatus of Plateosaurus consists of at least 18 gastralial rows (Figure 1,2). The rows are V-shaped with the apices of the rows pointing cranially. The $1^{\text {st }}$ gastralial row consists of a chevron-shaped medial gastralium and a single pair of lateral gastralia (Figure 1.1-2, 2). The medial gastralium is obtusely angled with an angle of $110^{\circ}$ between the gastralial arms. The medial gastralium is relatively robust with a subrounded cross section at the medial part. The arms taper laterally and are slightly curved in the frontal plane. The distal end of the gastralial arms are flattened cranially to articulate with the adjacent lateral gastralium. A corresponding articulation facet is also found on the caudal aspect of the proximal end in the lateral gastralia. The lateral gastralia of the first row are as robust as the medial gastralium and do not taper laterally. In the frontal plane, the lateral gastralia are sigmoid in shape with a subrounded cross section. The lateral gastralia are 2.5 times longer than the arms of the medial gastralium. From the $2^{\text {nd }}$ to the penultimate row of the gastralial skeleton of Plateosaurus, a gastralial row consists of four elements, a pair of a medial and a lateral gastralium on either side (Figure 1,2). The pairs are offset axial symmetric, resulting in an imbricating articulation of the proximal ends of the medial gastralia. The degree of overlap of the proximal ends of the medial gastralia decreases from cranially to caudally (Figure 1.4-5, 2). The gastra- 


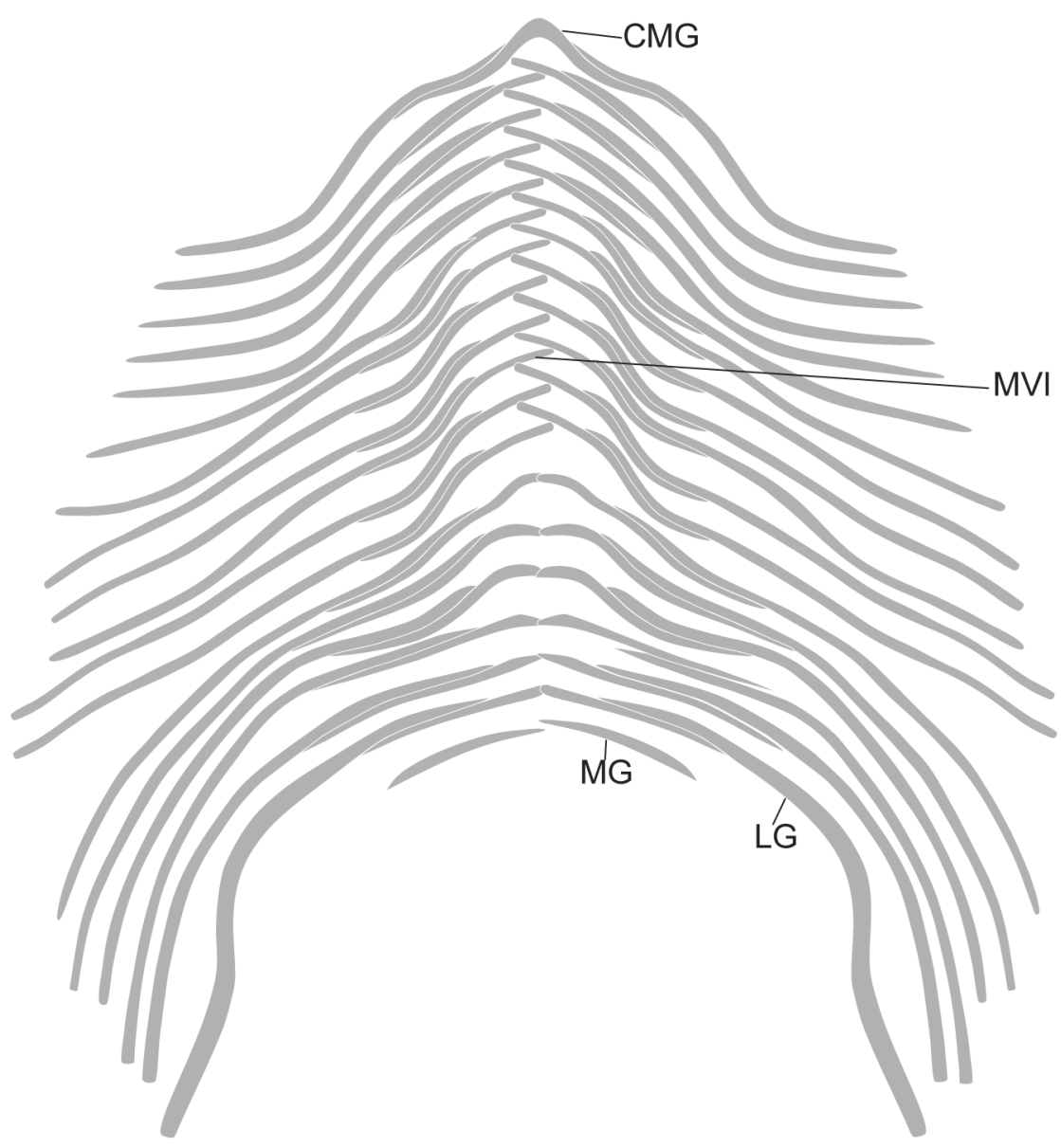

FIGURE 2. Interpretative drawing of the gastralial apparatus of Plateosaurus engelhardti based on specimens SMNS 12949, SMNS 12950, SMNS 52968. Abbreviations: CMG, chevron-shaped medial gastralium; LG, lateral gastralium; MG, medial gastralium; MVI, mid-ventral imbricating articulation. Not to scale.

lial rows are obtusely angled, ranging from about $110^{\circ}$ cranially to $140^{\circ}$ caudally (Figure $1.4-5,2$ ). The morphology of the medial and lateral gastralia changes from cranial to caudal. Cranially, the medial gastralia are slender and rod-shaped bones, which taper laterally. The distal end of the medial gastralia is flattened cranially to provide an articulation facet for the lateral gastralia. In the frontal plane, the medial gastralia are sigmoid in shape. The lateral gastralia are more robust than the adjacent medial gastralia. The rod-shaped bones are proximocaudally flattened (see above) and do not taper laterally. The lateral gastralia are strongly sigmoid. The morphology of the gastralia of the last gastralial rows changes drastically (Figure $1.1,1.3-5,2)$. The medial gastralia become more robust and the caudalmost medial gastralia is almost as robust as the associated gastralia, and the curvature in the frontal plane is lost. The lateral gastralia also lost the curvature in the frontal plane. Instead, the distal end of the lateral gastralia is strongly curved caudally or caudodorsally. The distal end of the gastralia is flattened dorsoventrally and broadened craniocaudally. The lateral gastralia are longer by a factor 2.2 to 2.8 than the associated medial gastralia. The last gastralial row preserved in Plateosaurus consists of paired medial gastralia. No lateral gastralia are preserved. However, the medial gastralia are not completely preserved and the absence of lateral gastralia in the last gastralial row could represent a preservation bias. The preserved fragments of the medial gastralia are relatively robust and almost straight. In these last gastralial rows, there is no evidence of a mid-ventral imbricating articulation (Figure 1.4-5, 2). 


\section{DISCUSSION}

\section{General Notes on the Gastralial Apparatus of Non-sauropodan Sauropodomorph Dinosaurs}

Gastralial remains of dinosaurs have rarely been described and illustrated and therefore our knowledge on the gastralial apparatus of non-sauropodan sauropodomorph dinosaurs was mainly based on isolated material (see Claessens, 2004). The articulated and almost complete gastralial remains described here provide new insights into the morphology of the gastralial apparatus of Plateosaurus engelhardti and improve our understanding of the gastralial apparatus of nonsauropodan sauropodomorph dinosaurs. Combining new insights presented here with published data (Huene, 1907-08, 1915; Cooper, 1981; Claessens, 2004; Knoll, 2010; Sertich et al., 2010) indicates that the gastralial apparatus of non-sauropod sauropdomorph share the following features: (1) gastralial rows consisting of two medial and two lateral gastralia, (2) medial gastralia are shorter than lateral gastralia, (3) medial and lateral gastralia are sigmoid-shaped, (4) caudolateral gastralia are broad and strongly curved caudally, (5) presence of a mid-ventral imbricating articulation, and (6) obtuse angle of gastralial rows increases from proximal to distal. A chevron-shaped medial gastralium of the first gastralial row as described here for Plateosaurus is not known from any other nonsauropodan sauropodomorph gastralial remains. However, the presence of a chevron-shaped medial gastralium in theropod dinosaurs (see Claessens, 2004) indicates that this element might also be present in other non-sauropodan sauropodomorph dinosaurs. Unfortunately, the fragmentary record of the gastralial material assigned to non-sauropodan sauropodomorph dinosaurs does not allow for identifying variation or phylogenetic changes in the gastralial apparatus in this group. Based on our current knowledge, the gastralial apparatus of non-sauropodan sauropodomorph dinosaurs resembles in its overall morphology that of theropod dinosaurs. So far, only the sigmoid shape of the gastralia can be identified as characteristic for non-sauropodan sauropodomorph dinosaurs.

\section{The Ventral Abdominal Wall in Plateosaurus engelhardti}

In extant tetrapods, a gastralial apparatus is present in crocodiles and Sphenodon. In both crocodiles (Figure 3.2) and Sphenodon the gastralial apparatus is embedded into $\mathrm{m}$. rectus abdominis (e.g., Romer, 1923; Byerly, 1925; Fechner and Schwarz-Wings, 2013). Thus, the reconstruction of the gastralial apparatus embedded into $\mathrm{m}$. rectus abdominis is unequivocally supported in Plateosaurus. In extant archosaurs, $m$. rectus abdominis originates from the caudal aspect of the sternum. In crocodiles, $m$. rectus abdominis inserts on the last gastralial row. The last gastralial row, in turn, is attached to the distal end pubis by a fibrocartilaginous sheet and ligaments, connecting the gastralial apparatus indirectly to the pubis (Maurer, 1896; Romer, 1923; Farmer and Carrier, 2000). In birds, $\mathrm{m}$. rectus abdominis inserts directly on the anteroventral aspect of the distal end of the pubis. The origin of $\mathrm{m}$. rectus abdominis on the sternum in Plateosaurus is unequivocally supported. Evidence from the distal end of the pubis indicates the presence of a cartilaginous cap (Figure 3.5). This cartilaginous cap and the propubic condition of the pelvis of Plateosaurus suggest that the insertion of $\mathrm{m}$. rectus abdominis was comparable to crocodiles (Figure 3.1-4). This reconstruction is supported by the observations of Huene (1915), who noticed that in Plateosaurus gracilis (GPIT 18392) the last gastralial row was located directly in front of the distal end of the pubis, with the lateral gastralia embracing the distal pubis laterally, and by the in situ drawing of the specimen SMNS 13200 (Schoch, 2011, figure 5A). In crocodiles additional abdominal muscles, most likely derivates of $\mathrm{m}$. rectus abdominis, are present (Fechner and Schwarz-Wings, 2013). The presence of these muscles in Plateosaurus is not discussed here and for more detailed information as well as a critical discussion of their homology and evolution, please refer to Fechner and Schwarz-Wings (2013).

$M$. rectus abdominis is part of the abdominal hypaxial muscle group. Apart of $\mathrm{m}$. rectus abdominis, the abdominal hypaxial muscle group of tetrapods generally consists of $\mathrm{m}$. obliquus externus abdominis, $\mathrm{m}$. obliquus internus abdominis, and $\mathrm{m}$. transversus abdominis (e.g., Carrier, 1990; Romer and Parson, 1991). The muscles of the abdominal hypaxial muscle group are closely related. In crocodiles, the lateral ends of $\mathrm{m}$. rectus abdominis are attached to $\mathrm{m}$. obliquus externus abdominis via the Fascia lumbodorsalis. M. obliquus internus abdominis and $\mathrm{m}$. transversus abdominis arise from the Fascia lumbodorsalis and insert on $\mathrm{m}$. rectus abdominis (e.g., Romer, 1923; Fechner and Schwarz-Wings, 2013). This arrangement corresponds to the general arrangement of the hypaxial abdominal muscles in tetrapods (Carrier, 1990; 

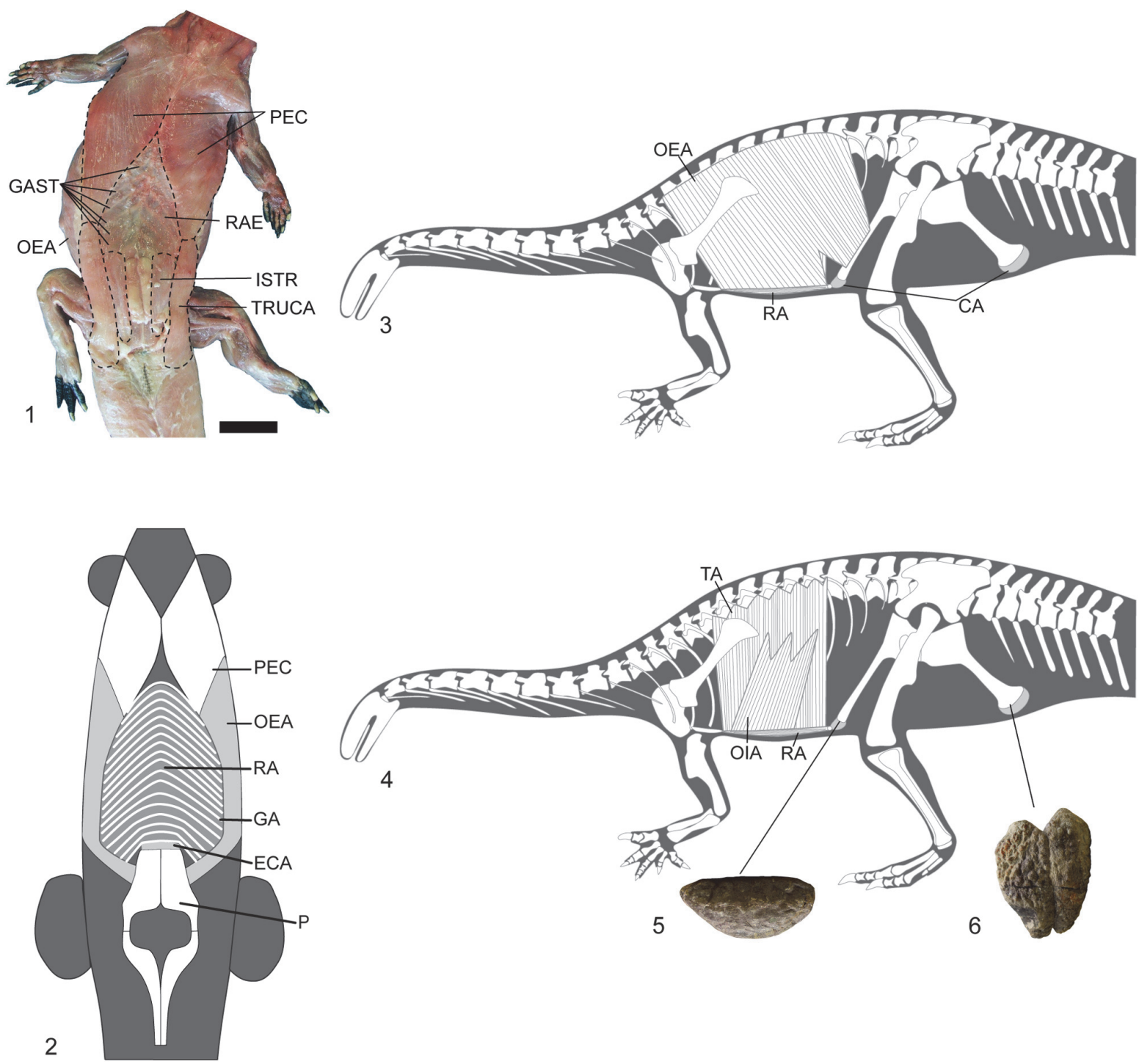

FIGURE 3. Reconstruction drawings of Plateosaurus engelhardti. 1, Crocodilus niloticus in dorsal view showing the association of gastralial apparatus and hypaxial abdominal muscles in extant crocodiles (scale bar equals $10 \mathrm{~cm}$ ); 2 , ventral view of the trunk of Plateosaurus engelhardti depicting the embedment of the gastralial apparatus into $\mathrm{m}$. rectus abdominis. The reconstructed gastralial apparatus does not show medial and lateral gastralia or the mid-ventral imbricating articulation (not to scale); 3, superficial layer and 4, internal layer of the left lateral view of Plateosaurus engelhardti depicting the abdominal hypaxial muscles. Orientation and length of muscle fibres are only of schematic nature; 5, distal end of the pubis and 6, ischium of specimen SMNS 13200 is indicative for the presence of a cartilaginous cap in Plateosaurus engelhardti (not to scale). Abbreviations: CA, cartilage; ECA, epipubic cartilage; GA, gastralial apparatus; GAST, gastralia; ISTR, m. ischiotruncus; OEA, m. obliquus externus abdominis; OIA, m. obliquus internus abdominis; $\mathrm{P}$, pubis; PEC, $\mathrm{m}$. pectoralis; RAE, $\mathrm{m}$. rectus abdominis externus; TA, $\mathrm{m}$. transversalis abdominis; TRUCA, m. truncocaudalis.

Romer and Parson, 1991) and can be reconstructed in Plateosaurus (Figure 3.1-4).

\section{The Function of the Gastralial Apparatus in Plateosaurus engelhardti}

In the past, the discussion on the function of the gastralial apparatus of tetrapods has focussed on two hypotheses: 1) protection and support of the viscera and 2) respiration. The hypothesis that the function of the gastralial apparatus of tetrapods is for protection and support of the viscera is based on its position on the ventral aspect of the trunk and the massive nature of the gastralia in basal tetrapods (Romer, 1956; Holtz and Sues, 1997). The 
delicate nature of the gastralia in Plateosaurus and other sauropodomorph dinosaurs (Huene, 190708, 1915; Cooper, 1981; Sertich and Loewen, 2010) indicates that protection and support of the viscera might not the primary function of the gastralia in this group. In recent years, only the potential respiratory role of the gastralial apparatus was largely discussed. Perry (1983) assumed a passive respiratory role of the gastralial apparatus in tetrapods, arguing that during costal breathing, the expansion of the rib cage is associated by a passive inward movement of the abdominal wall. This inward movement of the abdominal wall, however, will reduce the net expansion of the pleuroperitoneal cavity and therefore waste energy. According to Perry's understanding, the gastralial apparatus might serve as a structure that counteracts such a passive inward movement of the abdominal wall. Carrier and Farmer (2000) and Claessens (2004) argued for a more active respiratory role of the gastralial apparatus of saurischian dinosaurs. Thereby, Carrier and Farmer (2000) and Claessens (2004) based their assumption mainly on the activity pattern of $\mathrm{m}$. rectus abdominis in extant archosaurs and on the geometry of the saurischian gastralial apparatus. In extant archosaurs, m. rectus abdominis is active during expiration (Fedde, 1987; Baumel et al., 1990; Carrier and Farmer, 2000; Vollmerhaus, 2004). In crocodiles, contraction of $\mathrm{m}$. rectus abdominis decreases the distance between the gastralial rows, and the pubis is rotated craniodorsally. Both the contraction of $\mathrm{m}$. rectus abdominis and the craniodorsal rotation of the pubis result in a dorsal displacement of the abdominal wall and therewith in a decrease of the abdominal volume (Farmer and Carrier, 2000; Claessens, 2009). During inhalation, the ventral abdominal wall of crocodiles is displaced ventrally, resulting in an increase of abdominal volume (Farmer and Carrier, 2000; Claessens, 2009). Both Carrier and Farmer (2000) and Claessens (2004) concluded that the gastralial apparatus of saurischian dinosaurs with its mid-ventral imbricating articulation might represent an adaptation to a highly derived saurischian ventilatory mechanism. Thereby, the mid-ventral imbricating articulation function as a complicated lever-system, in which protraction and retraction of the gastralial rows widens and narrows the abdominal cavity by contraction of hypaxial abdominal muscles (Carrier and Farmer, 2000; Claessens, 2004). A recently published study on the lung ventilation in Alligator mississippiensis applying cineradiography showed that during exhalation the gastralial apparatus is displaced dorsally with the proximal ends of the gastralia displaced craniodorsally (Claessens, 2009). Claessens (2009) argued that the gastralial apparatus in Alligator might provide a skeletal framework for preventing an abdominal collapse (sensu Perry, 1983) and supporting muscle action during ventilation.

The hypaxial abdominal muscles including $\mathrm{m}$. rectus abdominis are of dual function: respiration and locomotion. In amphibians and reptiles, the abdominal hypaxial muscles allow for lateral bending of the trunk and stabilization of the trunk against long-axis torsion during walking (e.g., Carrier, 1990, 1993; Bennett et al., 2001). During walking, the trunk is supported by two diagonally opposing limbs. The ground reaction forces directed through the supporting limbs result in the rotation of the girdles and therewith in a twist of the long-axis of the trunk (Gray, 1968; Carrier, 1990; Bennett et al., 2001). In order to allow for trunk stabilization, muscle forces are required to counteract those torsional moments. It has been found that the abdominal hypaxial muscles are well suited to accomplish this task (Carrier, 1990, 1993; Bennett et al., 2001). The activity of $\mathrm{m}$. obliquus internus abdominis and $\mathrm{m}$. transversus abdominis on the extending side of the trunk is associated with forelimb support, and $\mathrm{m}$. obliquus externus abdominis is active on the flexing side of the trunk and associated with hind limb support (Carrier, 1990; Bennett et al., 2001). M. rectus abdominis is associated with lateral bending of trunk (Carrier, 1990). The work of Carrier $(1990,1993)$ and Bennett et al. (2001) refer to amphibians and lizards and therewith tetrapods with a sprawling limb posture and a quadrupedal body posture. For tetrapods with an erect limb posture (e.g., Gray, 1968; Fife et al., 2001; Deban and Carrier, 2002) and bipedal body posture (e.g., Waters and Morris, 1972; Borghuis et al., 2008) comparative findings have been obtained. This suggests that the abdominal hypaxial muscles are of dual function in Plateosaurus and other extinct archosaurs.

It is commonly accepted that a bone is shaped by the mechanical loads imposed on it and optimized in terms that minimum bone mass with maximum bone strength (e.g., Rubin and Lanyon, 1987; Christen et al., 2012). At both the developmental and evolutionary scale, changes in the mechanical loads are correlated with changes in its shape (e.g., Moss and Salentijn, 1969; Barak et al., 2011). A bone or bone complex, however, can be adapted to more than one function (Bock and Wahlert, 1969) and in such cases its resulting 
shape has to be regarded as a compromise. Each function of a bone or a bone complex is subject to selective forces (Bock and Wahlert, 1969; Currey, 2012). If one wants to analyze the cause and/or the change in shape, it is necessary to identify all the functions associated with the bone or bone complex; then the function or functions responsible for the change in shape can be detected. The relationship between function and shape, however, is very complex and fundamental aspects of the function shape relationship of most anatomical structures is not yet fully understood. The gastralial apparatus of extant tetrapods has rarely been subjected to functional morphological studies (e.g., Claessens, 2009). In extant tetrapods a gastralial apparatus is only present in Sphenodon and crocodiles. Further functional morphological studies have the potential to provide new insights into the function of the gastralial apparatus, supporting or confuting existing hypotheses. Such studies might show whether those findings can be applied to extinct tetrapods, such as sauropod dinosaurs, which differ from Sphenodon and crocodiles regarding body and limb posture, trunk stabilization, and ventilatory mechanism.

Based on the findings presented here, trunk stabilization most likely represents a function of the gastralial apparatus of Plateosaurus. Whether the gastralial apparatus of Plateosaurus assumes an active role or a passive role in trunk stabilization cannot be answered. Nevertheless, it is very likely that the function of the gastralial apparatus of Plateosaurus includes, besides trunk stabilization, respiration, and support and protection of the viscera, as suggested in previous studies. In order to improve our understanding of its function, the gastralial apparatus has to be regarded as an integral part of a whole organism, and methods that are well-suited to identify and simulate functions and their changes through ontogeny and phylogeny should be applied.

\section{ACKNOWLEDGMENTS}

The authors thank R. Schoch for access to material in his care, H. Preuschoft, N. Sverdlova, and S. Perry for discussions on the functional morphology of gastralia and archosaur physiology, E. Tschopp for discussions on potential gastralial remains in sauropod dinosaurs, C. Distler and S. Klenner for assistance in dissecting extant archosaur, L. Claessens, D. Pol, the editor of Palaeontologia Electronica J. Louys, and two anonymous reviewers for helpful comments on an earlier draft of this manuscript. The Deutsche Forschungsgemeinschaft (DFG) grant FE 1115/1-1 supported this research.

\section{REFERENCES}

Barak, M.M., Lieberman, D.E., and Hublin, J.-J. 2011. A Wolff in sheep's clothing: Trabecular bone adaptation in response to changes in joint loading orientation. Bone, 49:1141-1151.

Barsbold, R.A.1983. [Carnivorous dinosaurs from the Cretaceous of Mongolia]. Sovmestnaya SovetskoMongol'skaya Paleontologicheskaya Ekspeditsiya. Trudy, 19:1-117.

Baumel, J.J., Wilson, J.A., and Bergren, D.R. 1990. The ventilatory movements of the avian pelvis and tail: function of the muscles of the tail region of the pigeon (Columba livia). Journal of Experimental Biology, 151:263-277.

Bennett, W.O., Simons, R.S., and Brainerd, E.L. 2001. Twisting and bending: the functional role of salamander lateral hypaxial musculature during locomotion. Journal of Experimental Biology, 204:1979-1989.

Bock, W. and von Wahlert, G. 1965. Adaptation and the form-function complex. Evolution, 19:269-299.

Borghuis, J., Hof, A.L., and Lemmink, K.A.P.M. 2008. The importance of sensory-motor control in providing core stability. Sports Medicine, 38:893-916.

Byerly, T.C. 1925. The myology of Sphenodon punctatum. Studies in Natural History, 1-30.

Carrier, D.R. 1990. Activity of the hypaxial muscles during walking in the lizard Iguana iguana. Journal of Experimental Biology, 152:453-470.

Carrier, D.R. 1993. Action of the hypaxial muscles during walking and swimming in the salamander Dicamptodon ensatus. Journal of Experimental Biology, 180:75-83.

Carrier, D.R. and Farmer, C.G. 2000. The evolution of pelvic aspiration in archosaurs. Paleobiology, 26(2):271-293.

Christen, P., Rietbergen, B., Lambers, F.M., Müller, R., and Ito, K. 2012. Bone morphology allows estimation of loading history in a murine model of bone adaptation. Biomechanics and Modeling in Mechanobiology, 11:483-492.

Chure, D.J. and Madsen, J.H. 1996. On the presence of furculae in some non-maniraptorian theropods. Journal of Vertebrate Paleontology, 16:573-577.

Claessens, L.P.A.M. 2004. Dinosaur gastralia; origin, morphology, and function. Journal of Vertebrate Paleontology, 24:89-106.

Claessens, L.P.A.M. 2009. A cineradiographic study of lung ventilation in Alligator mississippiensis. Journal of Experimental Zoology Part B: Molecular and Developmental Evolution, 311A:563-585.

Cong, L., Hou, L., Wu, X., and Hou, J. 1998. [The gross anatomy of Alligator sinensis Fauvel]. Academia Sinica, Beijing. [Chinese] 
Cooper, M. 1981. The prosauropod dinosaur Massospondylus carinatus OWEN from Zimbabwe: its biology, mode of life and phylogenetic significance. Occasional Papers of the National Museums and Monuments of Rhodesia, Series B, Natural Sciences, 6:690-840.

Currey, J.D. 2012. The structure and mechanics of bone. Journal of Material Sciences, 47:41-54.

Daiber, M. 1920-1921. Das Bauchrippensystem von Sphenodon (Hatteria) punctatus GRAY. Anatomischer Anzeiger, 53:373-382.

Deban, S.M. and Carrier, D.R. 2002. Hypaxial muscle activity during running and breathing in dogs. Journal of Experimental Biology, 205:1953-1967.

Eudes-Deslongchamps, J.-A. 1838. Mémoire sur le Poekilopleuron bucklandii, grand saurien fossile, intermédiaire entre les crocodiles et les lézards. Mémoires du Société Linnéenne de Normandie, 6:37-146.

Farmer, C.G. and Carrier, D.R. 2000. Pelvic aspiration in the American alligator (Alligator mississippiensis). Journal of Experimental Biology, 203:1679-1687.

Fechner, R. and Schwarz-Wings, D. 2013. The muscles of the infrapubic abdominal wall of a 6-month-old Crocodylus niloticus (Reptilia: Crocodylia). Anatomia Histologia Embryologia, 42:175-182.

Fedde, M. 1987. Respiratory muscles, p. 3-94. In Seller, T. (ed.), Bird respiration. CRC Press, Boca Raton.

Fife, M.M., Bailey, C.L., Lee, D.V., and Carrier, D.R. 2001. Function of the oblique hypaxial muscles in trotting dogs. Journal of Experimental Biology, 204:2371-2381.

Gadow. 1882. Untersuchungen über die Bauchmuskeln der Krokodile, Eidechsen und Schildkröten. Morphologisches Jahrbuch, 7:57-100.

Gans, C. and Clark, B. 1976. Studies on ventilation of Caiman crocodilus (Crocodilia: Reptilia). Respiration Physiology, 26:285-301.

Gilmore, C.W. 1920. Osteology of the carnivorous Dinosauria in the United States National Museum. Bulletin of the United States National Museum, 11:1-159.

Gray, S.J. 1968. Animal Locomotion. WW Norton \& Company, New York.

He, X., Wang, C., Liu, S., Zhou, F., Liu, T., Cai, K., and Dai, B. 1998. [A new species of sauropod from the Early Jurassic of Gongxian Co., Sichuan]. Acta Geologica Sichuan, 18:1-8. [In Chinese]

Hildebrand, M. 1995. Analysis of Vertebrate Structure. John Wiley \& Sons, New York.

Holtz, T.R. and Brett-Surman, M.K. 1997. The osteology of the dinosaurs, p. 78-91. In Farlow, J.O. and BrettSurman, M.K. (eds.), The complete dinosaur. Indiana University Press, Bloomington.

Huene, F.v. 1907-1908. Die Dinosaurier der Europäischen Triasformation mit Berücksichtigung der aussereuropäischen Vorkommnisse. Geologische und Paläontologische Abhandlungen, Supplement 1:1-419.
Huene, F.v. 1915. Beiträge zur Kenntnis einiger Saurischier der schwäbischen Trias. Neues Jahrbuch für Mineralogie, 1915:1-27.

Knoll, F. 2010. A primitive sauropodomorph from the upper Elliot Formation of Lesotho. Geological Magazine, 147:814-829.

Lambe, L.M. 1917. The Cretaceous carnivorous dinosaur Gorgosaurus. Geological Survey of Canada, Memoir, 100:1-84.

Maurer, F. 1896. Die ventrale Rumpfmuskulatur einiger Reptilien. Festschrift zum Siebenzigsten Geburtstage Carl Gegenbaur Band l:182-256.

Moss, M.L. and Salentijn, L. 1969. The capsular matrix. American Journal of Orthodontics, 56:474-490.

Norell, M.A. and Makovicky, P.J. 1997. Important features of the dromaeosaur skeleton: information from a new specimen. American Museum Novitates, 3215:1-28.

O'Connor, P.M. 2007. The postcranial axial skeleton of Majungasaurus crenatissimus (Theropoda : Abelisauridae) from the Late Cretaceous of Madagascar. Journal of Vertebrate Paleontology Memoir Series, 27 (Suppl. 2):127-162.

O'Reilly, J.C., Summers, A.P., and Ritter, D. 2000. The evolution of the functional role of trunk muscles during locomotion in adult amphibians. American Zoologist, 40:123-135.

Osborn, H.F. 1906. Tyrannosaurus, Upper Cretaceous carnivorous dinosaur (second communication). Bulletin of the American Museum of Natural History, 32:281-296.

Perry, S. 1983. Reptilian lungs. Functional anatomy and evolution. Advances in Anatomy, Embryology, and Cell Biology, 79:1-81.

Redman, P.D. and Filla, J. 1994. Apatosaurus yahnapin: a preliminary description of a new species of diplodocid dinosaur from the Late Jurassic Morrison Formation of southern Wyoming, the first sauropod dinosaur found with a complete set of "belly ribs," $p$. 159-178. Presented at the Forty-fourth annual field conference, Wyoming Geological Association Guidebook.

Robinson, J.A. 1975. The locomotion in plesiosaurs. Neues Jahrbuch für Geologie und Paläontologie, Abhandlungen, 149:286-332.

Robinson, J.A. 1977. Intracorporal force transmission in plesiosaurs. Neues Jahrbuch für Geologie und Paläontologie, Abhandlungen, 153:86-128.

Romer, A.S.1923. Crocodilian pelvic muscles and their avian and reptilian homologues. Bulletin of the American Museum of Natural History, 48:533-552.

Romer, A.S. 1956. Osteology of the reptiles. University of Chicago Press, Chicago.

Romer, A.S. and Parsons, T.S. 1991. Vergleichende Anatomie der Wirbeltiere. Verlag Paul Parey, Hamburg. 
Rubin, C.T. and Lanyon, L.E. 1987. Osteoregulatory nature of mechanical stimuli: function as a determinant for adaptive remodeling in bone. Journal of Orthopaedic Research, 5:300-310.

Schoch, R.R. 2011. Tracing SEEMANN's dinosaur excavation in the Upper Triassic of Trossingen: his field notes and the present status of the material. Palaeodiversity, 4:245-282.

Sereno, P.C., Beck, A.L., Dutheil, D.B., Larsson, H.C., Lyon, G.H., Moussa, B., Sadleir, R.W., Sidor, C.A., Varricchio, D.J., Wilson, G.P., and Wilson, J.A. 1999. Cretaceous sauropods from the Sahara and the uneven rate of skeletal evolution among dinosaurs. Science, 286:1342-1347.

Sertich, J. and Loewen, M. 2010. A new basal sauropodomorph dinosaur from the Lower Jurassic Navajo Sandstone of southern Utah. PLoS ONE, 5(3):e9789.

Tschopp, E. and Mateus, O. 2013. Clavicles, interclavicles, gastralia, and sternal ribs in sauropod dinosaurs: new reports from Diplodocidae and their morphological, functional and evolutionary implications. Journal of Anatomy, 222(3):321-340.
Vanden Berge, J.C. and Zweers, G. 1993. Myologia, p. 189-247. In Baumel, J.J. (ed.), Handbook of avian anatomy: nomina anatomica avium. Publications of the Nuttall Ornithological Club, Cambridge.

Vollmerhaus, B. 2004. Lehrbuch der Anatomie der Haustiere. Band 5. Parey Verlag, Stuttgart.

Waters, R.L. and Morris, J.M. 1972. Electrical activity of muscles of the trunk during walking. Journal of Anatomy, 111:191-199.

Witmer, L.M. 1995. Homology of facial structures in extant archosaurs (birds and crocodilians), with special reference to paranasal pneumaticity and nasal conchae. Journal of Morphology, 225:269-327.

Yates, A.M., Bonnan, M.F., Neveling, J., Chinsamy, A., and Blackbeard, M.G. 2010. A new transitional sauropodomorph dinosaur from the Early Jurassic of South Africa and the evolution of sauropod feeding and quadrupedalism. Proceedings of the Royal Society of London Series B-Biological Sciences, 277:787-794. 